\title{
IDENTIFIKASI BAKAT PESERTA DIDIK BERKEBUTUHAN KHUSUS (PDBK) DI MADRASAH INKLUSI KABUPATEN LOMBOK
}

\author{
Arif Widodo \\ PGSD, FKIP, Universitas Mataram \\ arifwidodo@unram.ac.id \\ Dyah Indraswati (Corresponding Author) \\ PGSD, FKIP, Universitas Mataram \\ dyahindraswati@unram.ac.id \\ Deni Sutisna, Nursaptini, Setiani Novitasari \\ PGSD, FKIP, Universitas Mataram \\ denisutisna@unram.ac.id, nursaptini@unram.ac.id, setianinovitasari@unram.ac.id
}

\begin{abstract}
Abstrak
Bakat merupakan kemampuan spesial yang dimiliki seseorang, tidak terkecuali dengan Peserta Didik Berkebutuhan Khusus (PDBK). Bakat yang terdapat pada PDBK seharusnya dapat terindentifikasi sejak dini agar program pembelajaran yang didapatkannya tepat sasaran sesuai dengan bakat dan kemampuan yang dimilikinya. Melalui pembelajaran dan layanan yang tepat diharapkan pengembangan bakat sebagai bekal masa depan PDBK dapat berjalan secara optimal. Penelitian ini bertujuan untuk mengidentifikasi bakat dari PDBK di MI NW Tanak Beak Kecamatan Narmada Kabupaten Lombok Barat. Masalah utama dalam penelitian ini adalah menjelaskan apakah semua PDBK telah teridentifikasi bakatnya dan juga mengidentifikasi bakat apa saja yang ada pada diri PDBK. Subyek dalam penelitian ini adalah PDBK yang berjumlah 54 orang. Pendekatan yang digunakan dalam penelitian ini adalah deskriptif kualitatif. Tahap penelitian terdiri dari pengumpulan data, analisis data dan penarikan kesimpulan. Pengumpulan data dilakukan dengan observasi, wawancara, dan dokumentasi. Analisis data dilakukan bersamaan dengan pengumpulan data di lapangan. Data yang telah terkumpul kemudian disajikan dalam bentuk tabel atau diagram kemudian dideskripsikan. Berdasarkan hasil penelitian sebagian besar dari PDBK belum teridentifikasi bakatnya. PDBK yang telah teridentifikasi bakatnya berada di kelas tinggi, sedangkan untuk kelas rendah belum teridentifikasi bakatnya. Sebagian besar PDBK mempunyai bakat dibidang olahraga, seni prakarya, dan sebagian kecil mempunyai bakat logis matematis, linguistik dan tilawah.
\end{abstract}

Kata Kunci: Bakat, Peserta Didik Berkebutuhan Khusus, Madrasah inklusi

\begin{abstract}
Talent is a special ability possessed by someone, is no exception to Students with Special Needs (PDBK). The talent that is in PDBK should be identified early so that the learning program it gets is right on target following its talents and abilities. Through appropriate learning and services, it is expected that talent development as a provision for the future of PDBK can run optimally. This study aims to identify the talent of
\end{abstract}


PDBK in MI NW Tanak Beak, Narmada District, West Lombok Regency. The main problem in this research is to explain whether all of the PDBK have been identified as talents and also identify what talents are in themselves PDBK. The subjects in this study were GDPK, amounting to 54 people. The approach used in this research is descriptive qualitative. The research phase consists of data collection, data analysis and concluding. Data collection is done through observation, interviews, and documentation. Data analysis is performed together with data collection in the field. The data that has been collected is then presented in the form of a table or diagram and then described. Based on the results of research, most of the GDPK talent has not been identified. PDBK whose talent has been identified is in the high class, whereas for the low class the talent has not been identified. Most PDBK have talents in sports, art, and a small proportion have logical-mathematical, linguistic and recitational talents.

Keywords : Talent, Students with Special Needs, Inclusive Madrasas

\section{PENDAHULUAN}

Peserta didik berkebutuhan khusus (PDBK) merupakan salah satu sumber daya manusia yang harus diperhitungkan. Tidak sedikit PDBK yang mampu mengharumkan nama bangsa dalam dunia internasioanal dengan prestasi yang dimilikinya. PDBK sebagai salah satu bagian dari anak bangsa merupakan anak yang memerlukan perhatian secara khusus karena memiliki keterbatasan tertentu baik secara fisik maupun non fisik. Salah satu keterbatasan yang dimiliki PDBK adalah ketidakmampuan dalam melakukan kegiatan sehari-hari secara mandiri, sehingga mereka memerlukan bantuan dari orang lain agar dapat melakukan aktivitas sehari-hari dengan normal (Lestari, 2017). Menurut (Nuryetty, 2011) ketidakmampuan seseorang untuk melakukan aktivitas sehari-hari secara normal disebut dengan kesulitan fungsional atau functional difficulty, yang terdiri dari kesulitan melihat, mendengar, berjalan, mengingat, berkonsentrasi atau berkomunikasi hingga kesulitan dalam mengurus diri sendiri. Ironisnya sebagian masyarakat masih menganggap penyandang disabilitas atau PDBK pada umumnya sebagai masyarakat kelas dua sehingga PDBK seringkali mengalami diskriminasi (Suminar, 2015). Diskriminasi terhadap PDBK masih sering dijumpai di dalam masyarakat tidak terkecuali dalam dunia pendidikan.

Dewasa ini perhatian terhadap PDBK telah menuai titik terang. Negara Barat telah mempelopori pendidikan inklusif hingga menyebar ke negara-negara berkembang, salah satunya adalah Indonesia. Pola pelayanan terhadap peserta didik berkebutuhan khusus (PDBK) di sekolah telah bergeser dari diskriminasi menuju layanan pendidikan inklusif (Dewi, Suryana, \& Widnyana, 2016). Layanan pendidikan yang diskriminatif sejatinya memang harus ditinggalkan karena tidak 
sesuai dengan prinsip dasar Hak Asasi Manusia (HAM). Lingkungan pendidikan harus menjadi pelopor implementasi HAM dengan memberikan kesempatan yang sama kepada PDBK untuk belajar bersama dengan teman-teman seusianya. PDBK dengan segala kekurangan maupun kelebihannya membutuhkan perhatian yang lebih dari guru dan lembaga pendidikan tempat mereka belajar, perhatian tersebut berupa layanan khusus agar mereka dapat belajar dengan baik. Hal ini sesuai dengan pendapat (Mardini, 2015) bahwa PDBK dalam proses pembelajaran di kelas reguler membutuhkan pendampingan khusus karena daya tangkap kognitif PDBK dan kemampuan lainnya berbeda dengan anak normal.

Peserta didik dengan kebutuhan khusus seharusnya memiliki kesempatan yang sama dalam hal pendidikan. Sekolah Luar Biasa (SLB) atau sekolah khusus yang telah dipersiapkan oleh pemerintah dengan ternyata belum mampu mengakomodir kebutuhan PDBK secara keseluruhan. Maka dari itu pemerintah membuat program pendidikan inklusif dengan mengintegrasikan sekolah reguler menjadi sekolah inklusi agar PDBK yang tidak dapat menjangkau SLB mendapatkan layanan pendidikan di sekolah inklusi tersebut. Pendidikan inklusif merupakan sistem layananan yang diberikan kepada PDBK dalam bidang pendidikan dengan memberikan kesempatan yang sama untuk belajar di sekolah terdekat pada kelas yang sama bersama dengan teman-teman seusianya (Hermanto, Wiyono, Imron, \& Arifin, 2016). Permendiknas No. 70 Tahun 2009 menyebutkan bahwa pendidikan inklusif adalah sistem penyelenggaraan pendidikan yang memberikan kesempatan kepada semua peserta didik yang memiliki kelainan dan memiliki potensi kecerdasan dan/atau bakat istimewa untuk mengikuti pendidikan atau pembelajaran dalam satu lingkungan pendidikan secara bersama-sama dengan peserta didik pada umumnya (Republik Indonesia, 2009). Pendidikan inklusif mengasumsikan pembelajaran secara berdampingan pada kelas yang sama dengan menampung peserta didik yang beragam dan menghargai keunikan karakter yang dibawa oleh masing-masing peserta didik (Tichá, Abery, Johnstone, Poghosyan, \& Hunt, 2018). Lebih lanjut (Tichá et al., 2018) menyatakan bahwa penerapan pendidikan inklusif tidaklah mudah, banyak masalah dan tantangan yang harus di selesaikan dalam pengembangan keterampilan sosial anak penyandang cacat di sekolah inklusi. Sekolah inklusi sendiri menurut (Hermanto et al., 2016) adalah sekolah yang menyelenggarakan pendidikan inklusif, menampung semua siswa pada kelas yang sama, menyediakan layanan yang layak sesuai dengan kebutuhan siswa serta memberikan bantuan dan dukungan agar keberhasilan siswa dalam belajar dapat tercapai. Sungguhpun demikian masih saja ditemukan anak PDBK yang tidak dapat mengenyam 
pendidikan inklusif dengan berbagai kendala seperti terkendala jarak dan lain-lain, kalaupun ada sekolah inklusi terdekat fasilitas yang sesuai dengan kebutuhan PDBK tersebut masih terbatas (Anjarsari, 2018).

Terdapat beberapa hasil penelitian yang menunjukkan bahwa pelaksanaan pendidikan inklusif belum maksimal salah satunya adalah dengan ditemukannya sekolah yang membatasi penerimaan PDBK. Hal ini dapat terlihat dari beberapa sekolah inklusi yang hanya menerima PDBK dengan kategori tertentu. Salah satu bentuk pengkategorian PDBK adalah dengan menerima PDBK yang mempunyai keterbatasan dalam aspek non fisik saja seperti disabilitas intelektual, lambat belajar dan disabilitas sensorik (Sulthon, 2019). Pendidikan inklusif pada hakikatnya tidak hanya sekedar memasukkan PDBK ke dalam sekolah reguler sehingga permasalahan telah selesai, namun yang terpenting adalah pola pelayanan terhadap anak tersebut harus sesuai dengan kebutuhan mereka, mengingat PDBK memiliki karakteristik yang khas dan unik (Kamaludin, 2015). Melalui pendidikan inklusif seperti ini dimungkinkan PDBK dapat berinteraksi secara wajar dengan teman sekolah, sehingga dapat berkembang lebih baik dan belajar keterampilan sosial karena teman sekolah merupakan miniatur masyarakat yang sesungguhnya (Kamaludin, 2015).

Lembaga pendidikan yang menyelenggarakan pendidikan inklusif dimungkinkan dapat mengembangkan minat dan bakat PDBK secara optimal. Terdapat kesulitan tersendiri dalam mengidentifikasi bakat yang dimiliki oleh PDBK. Oleh karena itu tidak heran jika banyak dari masyarakat tidak dapat mendeteksi bakat dan kemampuan yang dimiliki PDBK, implikasinya adalah pembullyan dan pendiskriminasian. Anak dengan kebutuhan khusus dianggap sebagai beban, bencana dan aib bagi keluarga bahkan masyarakat. Kebanyakan manusia lupa bahwa setiap manusia dilahirkan dengan kelebihan dan kekurangan masing-masing. Peran pendidikan dalam hal ini sangat penting dalam mengidentifikasi bakat dan potensi yang dimiliki PDBK sehingga pendiskriminasian tidak terjadi lagi. Pemberian layanan secara khusus terhadap PDBK merupakan salah satu cara untuk mengindentifikasi minat dan bakat yang dimilikinya. PDBK memiliki karakteristik khusus yang berbeda dengan anak-anak pada umumnya serta memiliki kesulitan tersendiri dalam mengikuti proses pembelajaran yang disebabkan oleh adanya kelainan baik secara fisik, emosi, mental, sosial, maupun kecerdasan dan bakat istimewa. Kelainan tersebut menyebabkan berkurang atau berlebihnya potensi yang dimiliki PDBK. Oleh karena itu masingmasing PDBK membutuhkan layanan khusus dalam pembelajaran, terlebih lagi dalam 
pengidentifikasian dan pengembangan bakat yang dimilikinya. Pada hakikatnya setiap manusia mempunyai minat dan bakat sendiri-sendiri, namun yang sering terjadi adalah pengembangan bakat tidak optimal karena sejak dini tidak terdeteksi bakat yang dimiliki oleh peserta didik.

Pengertian bakat masih diperdebatkan para akademisi. Perdebatan tentang definisi bakat ini telah melahirkan banyak variasi dalam penelitian yang berkiatan dengan bakat (Hersi, 2016). Terlepas dari perdebatan tersebut hal yang paling penting dilakukan adalah langkah konkrit yang dibutuhkan oleh peserta didik berkebutuhan khusus, salah satunya adalah proses identifikasi. Menurut (Slater, 2018) proses identifikasi potensi atau bakat sangat penting untuk dilakukan sejak dini. Seorang guru dapat menerapkan bimbingan sampai dengan pemberian intervensi secara khusus jika telah mengetahui potensi bakat yang dimiliki PDBK sejak dini. Pemberian layanan pengembangan bakat disesuaikan dengan potensi yang ada dalam diri anak masing-masing. Guru sangat berperan dalam menentukan kualitas pendidikan inklusif, interaksi antara guru dengan siswa sangat penting dalam membuat lingkungan kelas yang baik sehingga pengembangan potensi siswa dapat maksimal (Kurniawati, 2018). Pengenalan atau identifikasi potensi bakat PDBK merupakan proses yang paling penting karena menentukan langkah selanjutnya dalam melakukan asesment. Proses asesment digunakan untuk menentukan program rencana pembelajaran dan pengembangan bakat dengan tepat. Identifikasi bakat merupakan upaya mengenali bakat anak berkebutuhan khusus, dengan melihat gejala-gejala yang menyertainya seperti kebiasaan, hobi, minat, kesenangan, dan kemampuan yang lebih dalam bidang tertentu. Identifikasi bakat PDBK tidak hanya sebagai suatu kegiatan dalam upaya menemukan anak yang berbakat, tetapi juga tindak lanjut dalam pengembangan tersebut. Identifikasi perlu dilakukan dengan cermat agar tidak terjadi salah penafsiran terhadap kondisi PDBK sehingga dapat menentukan tindak lanjut yang tepat.

Uraian di atas menunjukkan bahwa peran lembaga pendidikan sangat penting dalam mengidentifikasi dan mengembangan bakat PDBK. Salah satu lembaga pendidikan yang berkomitmen secara penuh dalam menyelenggarakan pendidikan inklusif adalah MI Nahdatul Wathan Tanak Beak yang terletak di kecamatan Narmada kabupaten Lombok Barat. Pada saat studi pendahuluan ditemukan 54 peserta didik di MI tersebut yang berkategori PDBK. Jumlah ini sangat fantastis, jika dapat dioptimalkan bakat yang dimilikinya maka akan menjadi potensi yang sangat besar untuk pembangunan bangsa. Berawal dari masalah tersebut penting untuk dilakukan penelitian dalam rangka mengidentifikasi bakat yang dimiliki oleh PDBK di MI NW Tanak Beak. 
Penelitian terdahulu yang membahas tentang PDBK diantaranya adalah penelitian (Nofiani, 2016) yang menunjukkan bahwa peran guru pendamping khusus dan guru reguler sangat penting dalam melakukan pembinaan terhadap minat dan bakat PDBK, pembinaan minat dan bakat dilakukan dengan melihat karakteristik siswa yang didasarkan pada hasil pembelajaran, mengidentifikasi rasa ingin tahu siswa, serta sikap siswa dalam keseharian. Penelitian selanjutnya dilakukan oleh (Yaum \& Mais, 2017) dengan melakukan identifikasi terhadap asesmen yang digunakan untuk PDBK, hasil penelitiannya menunjukkan bahwa guru PAUD telah mampu melakukan lesson study untuk pengembangan asesmen PDBK. Penelitian selanjutnya dilakukan oleh (Rofiah, 2015) dengan melakukan identifikasi terhadap anak kesulitan belajar tipe disleksia. Hasil penelitian tersebut menyatakan bahwa identifikasi dilakukan dengan mengumpulkan informasi yang relevan melalui pengamatan terhadap PDBK bagaimana perilakunya, kemampuan membacanya, kemampuan menulisnya dan kemampuan mengejanya. Identifikasi tersebut dilakukan secara sistematis dalam rangka pembuatan keputusan pembelajaran atau layanan khusus yang tepat. Ketiga penelitian di atas sama-sama mengidentifikasi PDBK, namun yang membedakan adalah pada penelitian yang pertama berfokus pada pengembangan minat dan bakat siswa oleh guru, pada penelitian kedua fokus penelitiannya adalah identifikasi asesmen yang digunakan untuk PDBK dan penelitian ketiga mengidentifikasi kesulitan belajar anak disleksia. Penelitian selanjutnya telah dilakukan oleh (Hersi, 2016) dengan tujuan utama dalam penelitian tersebut adalah mengkaji upaya awal dalam melakukan identifikasi terhadap bakat siswa disekolah dasar secara umum tanpa memandang siswa tersebut berkebutuhan khusus atau tidak. Penelitian yang akan dilakukan ini secara khusus dilaksanakan untuk mengidentifikasi bakat yang dimiliki oleh PDBK.

Tujuan dalam penelitian ini adalah mengidentifikasi bakat apa saja yang dimiliki oleh PDBK di MI NW Tanak Beak Narmada. Proses pengidentifikasian ini penting dilakukan agar guru sebagai pembimbing utama PDBK tidak salah dalam memberikan layanan pengembangan bakat kepada PDBK. Masalah utama dalam penelitian ini diantaranya (1). apakah semua PDBK telah teridentifikasi bakatnya. 2. bakat apa saja yang dimiliki oleh siswa PDBK di MI NW Tanak Beak. 3 prestasi apa saja yang pernah diraih PDBK di MI NW Tanak Beak. 


\section{METODE}

Jenis penelitian yang digunakan adalah kualitatif dengan pendekatan deskriptif. Penelitian dilakukan melalui berbagai tahapan penelitian diantaranya studi pendahuluan, perumusan masalah, penyusunan instrument penelitian, pengumpulan data, analisis data dan penyusunan laporan penelitian. Pengumpulan data dilakukan dengan wawancara, oservasi dan dokumentasi. Instrument yang digunakan berupa pedoman wawancara dan pedoman observasi. Data yang telah diperoleh diklasifikasikan dan disajikan dalam bentuk tabel dan diagram agar dalam memahami fenomena yang ada menjadi lebih mudah, selain itu data juga disajikan dalam bentuk deskriptif terutama data yang didapatkan dari hasil wawancara. Subyek dalam penelitian ini adalah, guru, kepala sekolah dan PDBK di MI NW Tanak Beak Narmada. Guru menjadi narasumber utama dalam penelitian ini karena gurulah yang setiap hari membimbing para PDBK sehingga dapat mengetahui perkembangan dalam bidang akademik maupun non akademik, berdasarkan pandangan itu dapat dikatakan bahwa gurulah yang paling memahami bakat para PDBK. Guru yang menjadi narasumber adalah guru kelas dan guru pendamping khusus (GPK). Selain itu untuk memperkuat data penelitian wawancara juga dilakukan kepada kepala sekolah, beberapa orang tua PDBK dan PDBK itu sendiri. Pengecekan keabsahan temuan dilakukan dengan triangulasi sumber, membandingkan hasil wawancara dengan hasil observasi di lapangan. Analisis data dilakukan secara bersamaan pada saat pengumpulan data di lapangan.

\section{HASIL DAN PEMBAHASAN}

Penelitian ini dilakukan di MI NW Tanak Beak Narmada pada bulan November 2019. Data yang berkaitan dengan identifikasi bakat PDBK di MI NW dapat disajikan dalam diagram berikut:

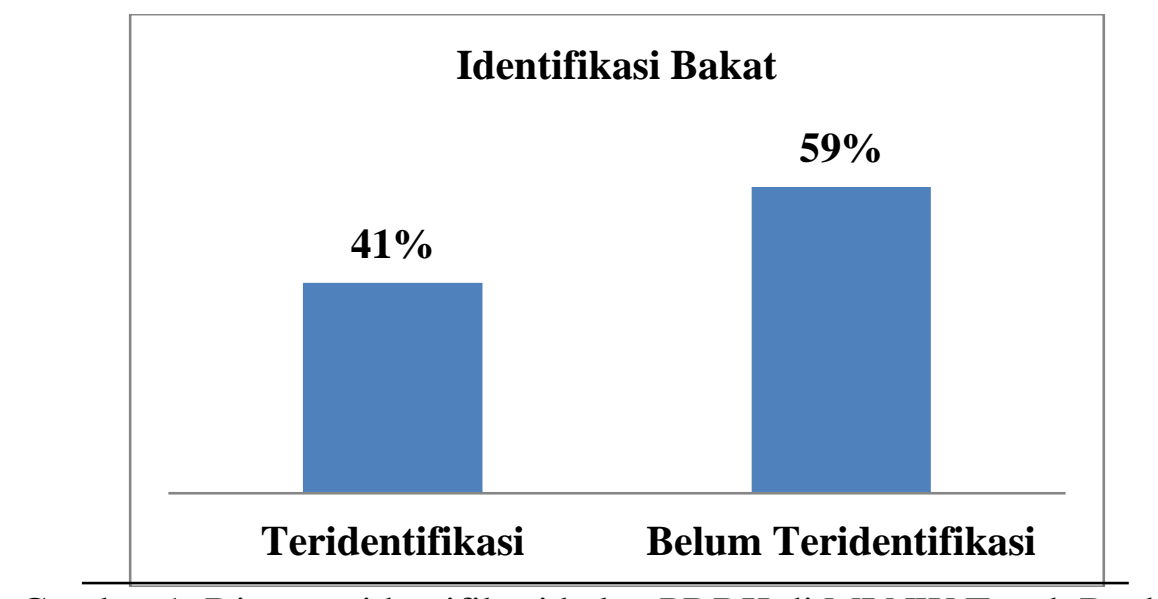

Gambar 1. Diagram identifikasi bakat PDBK di MI NW Tanak Beak 
Berdasarkan gambar di atas dapat diketahui bahwa sebanyak 41\% dari 54 PDBK telah teridentifikasi bakatnya atau sejumlah 22 peserta didik. Jumlah PDBK yang belum teridentifikasi bakatnya sebanyak 59\% atau sejumlah 32 peserta didik. Data di atas menunjukkan bahwa sebagian besar peserta didik belum teridentifikasi bakatnya. Kondisi tersebut merupakan permasalahan yang harus segera dipikirkan. Belum teridentifikasinya bakat PDBK menunjukkan pelayanan terhadap bakat PDBK belum optimal sehingga perlu diupayakan solusinya agar bakat PDBK dapat segera teridentifikasi. Dari 22 PDBK yang telah teridentifikasi, potensi bakatnya dapat diklasifikasikan dalam diagram di bawah ini:

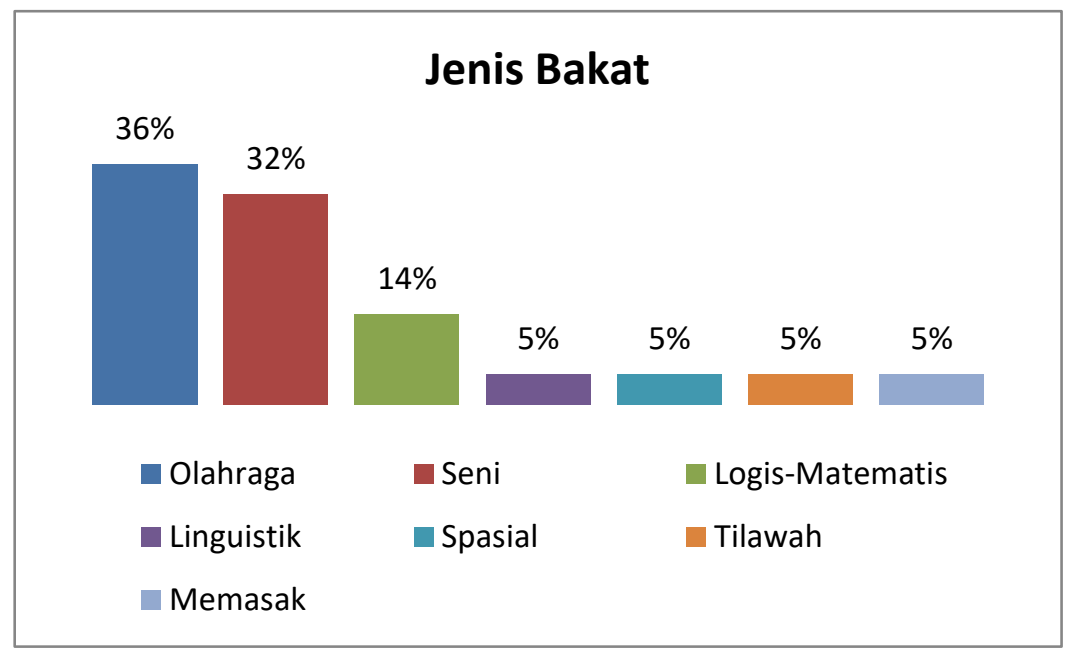

Gambar 2. Jenis Bakat PDBK

Berdasarkan gambar di atas dapat diketahui bahwa dari 22 PDBK yang telah teridentifikasi bakatnya, sebesar 36\% atau sejumlah 8 peserta didik berbakat dalam bidang oleh raga. Sebesar 32\% atau sejumlah 7 peserta didik berbakat dalam bidang seni. Sebesar 14\% atau sejumlah 3 peserta didik berbakat dalam bidang logis matematis. Selanjutnya berbakat dalam bidang linguistik, spasial, tilawah dan memasak yang besarnya masing masing adalah 5\% atau sebanyak 1 peserta didik. Data di atas menunjukkan bahwa sebagian besar peserta didik berbakat dalam bidang olah raga. Berdasarkan penuturan guru pembimbing khusus dapat diketahui bahwa olah raga yang diminati oleh peserta didik adalah sepak bola, bulu tangkis, dan karate. Bidang seni yang diminati PDBK diantaranya adalah seni prakarya, musik, dan dekorasi. Seni prakarya yang dikembangkan dalam kegiatan sekolah dengan memanfaatkan barang bekas. Produk yang dihasilkan diantaranya hiasan dinding, vas bunga, bunga imitasi, dan pot bunga. Berikut ini disajikan beberapa dokumentasi yang berkaitan dengan kegiatan prakarya PDBK. 


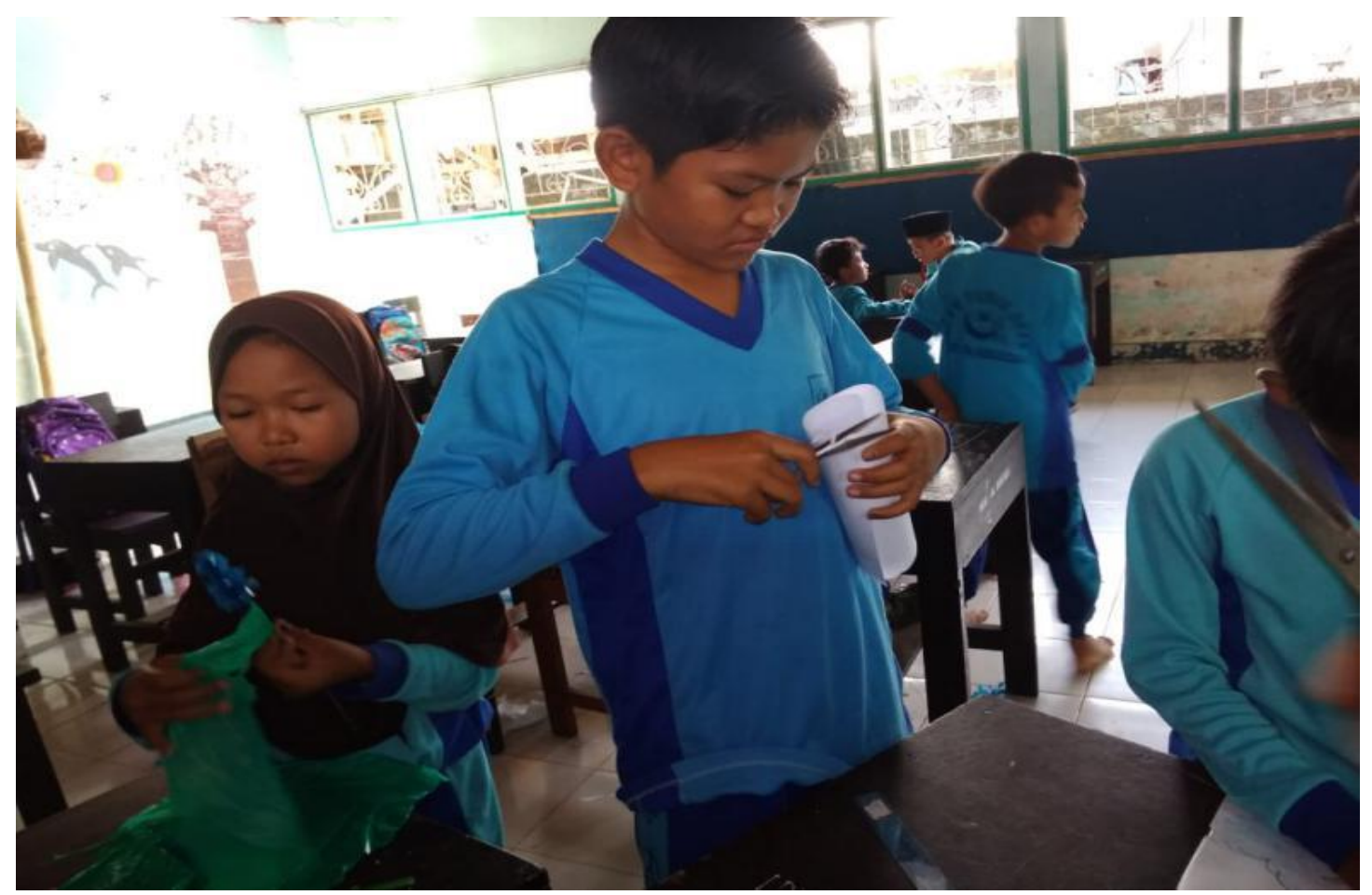

Gambar 3. PDBK belajar membuat prakarya dari bahan bekas

Gambar di atas menunjukkan beberapa PDBK sedang berbaur dengan teman sekelasnya untuk berlatih membuat kerajinan dari bahan bekas. PDBK berbaur dengan teman sekelasnya agar tercipta proses sosialisasi. Melalui kegiatan seperti ini diharapkan selain dapat menyalurkan bakat dan kreativitas keterampilan sosial PDBK dapat terbentuk. Hal ini sesuai dengan pernyataan (Yaum \& Mais, 2017) bahwasannya inklusi merupakan integrasi yang menyeluruh untuk semua siswa tanpa terkecuali peserta didik dengan kebutuhan khusus dalam kelas regular yang disesuaikan dengan umur siswa dan letak sekolah. Hasil yang dapat dirasakan adalah kerjasama antar peserta didik dapat berjalan dengan baik. Hal ini dapat tercermin ketika beberapa PDBK menjadi kreator dalam mendekorasi ruangan dengan dibantu oleh peserta didik yang lain. Berikut dapat disajikan dokumentasi ketika PDBK mendekorasi ruangan dalam rangka menyambut hari guru tanggal 25 November: 


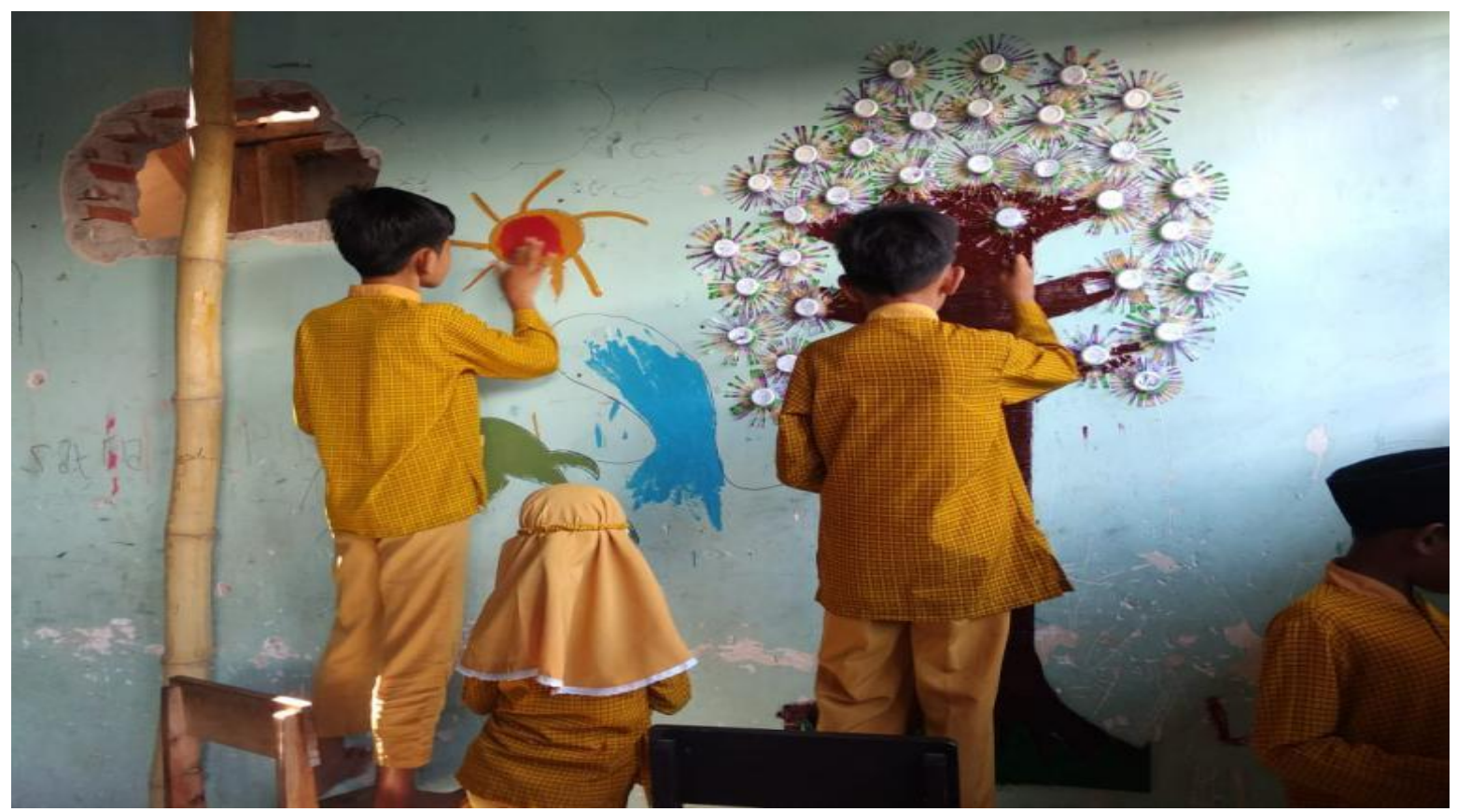

Gambar 4. PDBK mendekorasi dinding untuk peringatan hari guru

Gambar di atas memperlihatkan beberapa PDBK sedang mendekorasi ruangan, teman-teman yang lain ikut membantu hingga kegiatan mendekorasi ruangan selesai. Bakat seni dekorasi dapat dikembangkan melalui kegiatan ini. Bakat sebagai kemampuan yang dimiliki seseorang sejak lahir tidak akan berkembang dengan baik jika tidak didukung oleh lingkungan yang sesuai dengan perkembangan bakat tersebut, begitu juga sebaliknya sebaik apapun dukungan dari lingkungan jika dalam diri seseorang tidak ada bakat maka tidak akan menghasilkan perkembangan yang optimal.

Berdasarkan hasil wawancara dengan kepala madrasah tidak ada pembatasan PDBK yang dapat diterima di madrasah ini, mengingat madrasah ini telah berkomitmen untuk menjadi pelopor madrasah inklusi. Kepala madrasah pada awalnya merasa kesulitan untuk meyakinkan masyarakat sekitar dengan program madrasah inklusi tersebut, namun seiring berjalannya waktu melalui penjelasan dan pendekatan terhadap tokoh masyarakat akhirnya madrasah ini dipercaya sebagai penyelenggara pendidikan inklusif. Hal ini terbukti dengan semakin besarnya jumlah peserta didik yang ada di madrasah ini. Kepala madrasah lebih lanjut mengatakan bahwa untuk memberikan pelayanan yang maksimal terhadap PDBK selain guru kelas telah disediakan dua Guru Pembimbing Khusus (GPK). GPK bertugas untuk memberikan layanan secara khusus kepada PDBK di kelas inklusi. 
Menurut keterangan GPK proses pembelajaran PDBK dapat dilakukan bersamaan dengan kelas normal atau bisa juga diinklusifkan sesuai dengan tingkat kebutuhannya. Pembedaan tersebut bukan berarti diskriminasi tetapi sebuah upaya dalam memberikan layanan khusus kepada PDBK. Terdapat dua macam pelayanan dalam menyelenggarakan pendidikan inklusif di sekolah yaitu melalui kelas reguler dan kelas inklusi. Kelas reguler merupakan kelas yang digunakan oleh siswa pada umumnya, sedangkan kelas inklusi adalah kelas khusus untuk PDBK yang terpisah dari siswa umum. Menurut (Mardini, 2015) pelaksanaan pembelajaran dapat juga dilakukan dengan model Pull Out yaitu PDBK belajar di kelas reguler bersama dengan teman-teman seusianya akan tetapi pada waktu tertentu ditarik ke ruang sumber belajar untuk mendapatkan pelajaran dari guru pembimbing khusus. Pada saat-saat tertentu pemisahan siswa PDBK dari kelas reguler juga dibutuhkan agar minat belajar siswa PDBK lebih terbangun (Mardini, 2015). Model Pull Out ini juga diterapkan oleh GPK terutama dalam menghadapi PDBK dengan jenis hiperaktif, jika emosinya telah terkendali maka akan dikembalikan ke kelas reguler. Lebih lanjut GPK menjelaskan bahwa PDBK yang ditampung di sekolah ini sebagian besar adalah anak hiperaktif, tunagrahita, slow learner, tuna ganda dan beberapa kelainan lain yang tersebar secara merata mulai dari kelas 1 sampai dengan kelas 6. Jumlah PDBK secara keseluruhan diketahui sebanyak 54 peserta didik.

Bakat PDBK yang telah teridentifikasi menurut GPK sejauh ini baru kelas tinggi saja, sedangkan untuk kelas rendah belum teridentifikasi. Hal ini sesuai dengan pernyataan guru kelas II yang mengungkapkan bahwa untuk kelas rendah lebih fokus pada proses pengendalian peserta didik untuk dapat mengikuti pembelajaran, mengingat kelas rendah lebih sulit dikondisikan sehingga upaya untuk mengidentifikasi bakat belum bisa dilakukan. Sedikit berbeda dengan kelas tinggi, proses pengidentifikasian bakat lebih mudah dilakukan. Hal ini sesuai dengan keterangan guru kelas IV yang menyatakan bahwa melalui proses pengamatan PDBK telah teridentifikasi bakatnya. Jumlah PDBK di kelas IVA sebanyak 6 anak. Empat anak diantarannya hiperaktif dengan jenis kelamin laki-laki 3 anak dan perempuan 1 anak. Dua dari enam anak yang ada di kelas IV mengalami gangguan dalam belajar atau slow learner dengan jenis kelamin laki-laki dan perempuan. Bakat yang dimiliki oleh anak hiperaktif di kelas ini adalah olahraga seperti sepak bola, bulu tangkis dan karate. Satu anak yang mengalami lambat belajar tersebut kelemahannya adalah dalam membaca dan menulis, namun anak tesebut memiliki kemampuan lebih di bidang numerik. Menurut penuturan guru kelas anak tersebut memiliki kecepatan berhitung tiga kali lebih 
cepat jika dibandingkan dengan anak normal, namun kelemahannya dia cepat bosan di dalam kelas sehingga lebih suka belajar di luar kelas. Satu PDBK di kelas ini dengan inisial F mempunyai bakat seni yaitu mendekorasi ruangan. Berdasarkan hasil dokumentasi pada gambar 4 dapat terlihat hasil dekorasi dari anak PDBK ini cukup indah dan menarik untuk dikembangkan lebih lanjut.

Kelas dengan PDBK terbanyak berada di kelas VB yang berjumlah 8 anak. PDBK di kelas ini juga di dominasi oleh penderita hiperaktif dengan jumlah 5 anak dan sisanya adalah slow learner. Guru kelas VB menjelaskan bahwa 5 dari 8 PDBK di kelas ini telah teridentifikasi bakatnya, diantaranya adalah sepak bola, prakarya dan seni. Terdapat salah satu PDBK dengan inisial MA yang teridentifikasi mempunyai bakat spasial. Hal ini dapat terlihat dari kemampuan menggambar yang terlihat hidup dari setiap karyanya. Guru kelas VB menuturkan lebih lanjut bahwa MA ini sering mengajak gurunya untuk menggambar dari pada mempelajari materi pelajaran di kelas, bahkan seringkali MA ini membawa peralatan sendiri dari rumah seperti cat air dan sebagainya untuk keperluan menggambar dengan menyisihkan uang saku dari orang tuanya.

Terdapat 7 PDBK berada di kelas VI yang didominasi oleh hiperaktif, slow learner dan tuna daksa. Berdasarkan hasil wawancara dengan guru kelas VI bakat yang telah teridentifikasi diantaranya dalam bidang olahraga dan tilawati, bahkan ada satu PDBK dengan kelainan tunadaksa yang memperoleh prestasi cukup bagus dalam bidang akademik. PDBK tersebut konsisten berada diperingkat ketiga dalam perolehan hasil belajar setiap semester. PDBK dengan inisial SY mempunyai bakat dalam bidang tilawah. Berdasarkan hasil wawancara dengan orang tua SY dapat diketahui bahwa anaknya memang lebih suka baca alquran daripada membaca buku. Jika dipaksa untuk belajar tentang pelajaran disekolah anak tersebut akan berontak, sehingga mau tidak mau orang tua harus mengikuti kemauan anak tersebut. Pada akhirnya orang tua PDBK menyadari bahwa anaknya tidak bisa dipaksa untuk melakukan kegiatan yang tidak disukainya. Berawal dari sini orang tua berusaha memberikan dukungan terhadap bakat yang dimiliki anaknya dengan memanggil guru khusus untuk mengajari tilawah. Buah usaha dari orang tua tidaklah siasia sehingga anaknya mampu mewakili kecamatan dalam lomba tilawah tingkat kabupaten. Hal ini dapat dipahami bahwa selain dari guru dukungan orang tua sangat penting dalam mendongkrak prestasi dan pengembangan bakat PDBK (Tanjung \& Iswari, 2019). 


\section{KESIMPULAN}

Berdasarkan hasil penelitian dapat disimpulkan beberapa hal yang merupakan jawaban dari rumusan masalah, diantaranya adalah:

1. Belum semua PDBK di MI NW Tanak Beak telah teridentifikasi potensi bakatnya, karena sebagian besar dari PDBK belum dapat dikenali bakatnya. PDBK yang telah teridentifikasi bakatnya sebanyak $41 \%$ sedangkan $59 \%$ belum teridentifikasi bakatnya.

2. Jenis bakat yang paling banyak dimiliki oleh PDBK di MI NW Tanak Beak adalah olah raga sebesar 36\% atau sejumlah 8 peserta didik, bidang seni sebesar 32\% atau sejumlah 7 peserta didik, bidang logis matematis sebesar 14\% atau sejumlah 3 peserta didik, bidang linguistik, spasial, tilawah dan memasak yang besarnya masing masing adalah 5\% atau sebanyak 1 peserta didik.

3. Prestasi terbaik yang diperoleh PDBK adalah mewakili kecamatan dalam lomba tilawah tingkat kabupaten walaupun belum memperoleh juara. Prestasi dalam bidang akademik yang diperoleh PDBK adalah selalu konsisten mendapatkan peringkat ketiga walaupun mengalami tuna daksa.

\section{SARAN}

Berdasarkan simpulan di atas dapat diberikan beberapa saran diantaranya adalah:

1. Perlu dilakukan identifikasi potensi bakat PDBK secara optimal agar semua PDBK dapat diketahui potensi bakatnya.

2. Perlu dilakukan pengembangan lebih lanjut terhadap potensi bakat PDBK yang telah teridentifikasi agar potensi bakat yang ada dapat bermanfaat bagi masa depan PDBK.

3. Prestasi PDBK dalam bidang akademik maupun non akademik perlu ditingkatkan, mengingat hanya sedikit PDBK yang berprestasi di sekolah. 


\section{DAFTAR PUSTAKA}

Anjarsari, A. D. (2018). Penyelenggaraan pendidikan inklusi pada jenjang SD, SMP, dan SMA di Kabupaten Sidoarjo. JPI (Jurnal Pendidikan Inklusi), $1(2), \quad 91$. https://doi.org/10.26740/inklusi.v1n2.p91-104.

Dewi, K., Suryana, J., \& Widnyana, I. G. N. (2016). Proses pengajaran mewarnai di SLB-C Negeri Singaraja. Jurnal Pendidikan Seni Rupa Undiksha, 6(1). https://doi.org/http://dx.doi.org/10.23887/jjpsp.v6i1.8658.

Hermanto, H., Wiyono, B. B., Imron, A., \& Arifin, I. (2016). Analisis potensi dan masalah pada fase konseptualisasi pengembangan model supervisi pembelajaran di sekolah dasar inklusi. JKP (Jurnal Pendidikan Khusus), 12(1), 14-30. https://doi.org/10.21831/jpk.v12i1.12836.

Hersi, M. S. M. S. (2016). The Identification Process \& Tools for Gifted and Talented Students (The British University in Dubai). Retrieved from https://pdfs.semanticscholar.org/95e9/90bed8a61a2f8c00f9284c3af8fb906b70e4.pdf.

Kamaludin, A. (2015). Identifikasi media pembelajaran Kimia bagi peserta didik difabel netra dan rungu pada SMA/MA inklusi di Yogyakarta. INKLUSI, 2(2), 259. https://doi.org/10.14421/ijds.2205.

Kurniawati, F. (2018). Konstruksi Alat Ukur Interaksi Guru-Siswa di Sekolah Dasar Inklusif. INKLUSI, 5(1), 1. https://doi.org/10.14421/ijds.050101.

Lestari, F. (2017). Metode guru BK dalam mengatasi problem penyesuaian diri pada anak berkebutuhan khusus. INKLUSI, 2(2), 273. https://doi.org/10.14421/ijds. 2206.

Mardini, S. (2015). Increasing interest in learning children with special needs model through regular class pull out State Elementary School of Giwangan Yogyakarta. Jurnal.Uad.Ac.Id, 2(1). Retrieved from https://media.neliti.com/media/publications/71287-ID-meningkatkanminat-belajar-anak-berkebut.pdf.

Nofiani, E. (2016). Pembinaan minat dan bakat Peserta didik berkebutuhan khusus (PDBK) (Studi deskrpitif di sekolah dasar inklusi). In P. N. Prihatin, E. D. Mayasari, \& J. D. Sinaga (Eds.), PROSIDING SEMINAR NASIONAL REFORMING PEDAGOGY (pp. 9-14). Retrieved from https://www.usd.ac.id/seminar/snrp2016/wp-content/uploads/2017/01/SNRP02.pdf.

Nuryetty, M. T. (2011). Kesulitan fungsional penduduk Indonesia. In Badan Pusat Statistik. Retrieved from https://www.bps.go.id/publication/download.html?.

Republik Indonesia. Peraturan Menteri Pendidikan Nasional (Permendiknas) nomor 70 tahun 2009 tentang pendidikan inklusif bagi peserta didik yang memiliki kelainan dan memiliki potensi kecerdasan dan/atau bakat istimewa. , Pub. L. No. 70 (2009).

Rofiah, N. H. (2015). Proses identifikasi: Mengenal anak kesulitan belajar tipe disleksia bagi guru 
sekolah dasar inklusi. INKLUSI, 2(1), 109. https://doi.org/10.14421/ijds.020110

Slater, E. (2018). The identification of gifted children in Australia: The importance of policy. TalentEd, 30(1), $1 . \quad$ Retrieved from https://www.researchgate.net/profile/Eileen_Slater/publication/322419883.

Sulthon, S. (2019). Pendidikan Dasar Inklusif di Kabupaten Pati: Harapan dan Kenyataan. INKLUSI, 6(1), 151. https://doi.org/10.14421/ijds.060107.

Suminar, R. E. (2015). Identifikasi kemudahan penyandang difabilitas dalam melakukan pergerakan dengan menggunakan moda transportasi. INKLUSI, 2(1), 155. https://doi.org/10.14421/ijds.020107.

Tanjung, B. S., \& Iswari, M. (2019). Dukungan orangtua terhadap prestasi anak tunanetra di Sekolah Inklusi. JPI (Jurnal Pendidikan Inklusi), 3(1), 40. https://doi.org/10.26740/inklusi.v3n1.p40-47.

Tichá, R., Abery, B., Johnstone, C., Poghosyan, A., \& Hunt, P. (2018). Inclusive Education Strategies: $\quad$ A Textbook. Retrieved

from https://www.unicef.org/armenia/media/3501/file/Inclusive education strategies_Textbook_2018.pdf.

Yaum, L. A., \& Mais, A. (2017). Pelaksanaan lesson study identifikasi dan asesmen anak berkebutuhan khusus dalam setting pendidikan inklusif untuk anak usia dini pada guru PAUD di Kabupaten Jember. Pendidikan Dan Humaniora (Jurnal Pendidikan Dan Ilmu Pengetahuan Sosial), 57(1), 78-85. Retrieved from https://s3.amazonaws.com/academia.edu.documents/54705132/Artikel_Lailil_20171.pdf? 